\title{
Causes and Effects of Industrial Disputes in BHEL India
}

\author{
Bhawana $^{a}$, Arvind Kumar Yadav ${ }^{*}$ \\ aFaculty of Commerce and Business Administration, Meerut College, Meerut (U.P.) India \\ bFaculty of Commerce, K.M.G.G. (P.G.) College, Gautam Budh Nagar, (U.P.), India \\ Email Id:arvind3510@gmail.com
}

\begin{abstract}
An industrial dispute may be defined as a conflict or difference of opinion between management and workers on the terms of employment. It is a disagreement between an employer and employee's representative; usually a trade union, over pay and other working conditions and can result in industrial actions. Prevention is always better than cure and, therefore, first of all those methods which can prevent the occurrence of industrial disputes between Labour and Management in the organization will be focused upon. The immediate need of the hour is that of narrowing the gap between labour and management and to find out the means of establishing mutual trust between employers and the workers. In addition to bringing about a change in the attitude of the employers, who should directly take a personal interest in the welfare of the workers, there are other methods which suggest themselves in this connection. The first is the development of stable trade unions having access to the management. However, sooner or later, the employers and the workers must realize that they have to co-operate and resolve their differences between themselves, if both are to prosper. A strong trade union movement, schemes of workers co-operation and participation in management, atmosphere of trust and respect on both sides has to be established. Policy of human relations in industry will go a long way in establishment of industrial peace in the country. In this research paper, we have studied about labour management and causes of industrial disputes in BHEL India. Along with this we have also studied the effects of Industrial disputes in BHEL India.

Keywords: Conciliation officers, Arbitration, Dispute resolution, Industrial relations, Industrial Disputes and Industrial Tribunal.
\end{abstract}

\section{PAPER/ARTICLE INFO RECEIVED ON: 19/09/2019 ACCEPTED ON: 07/11/2019}

Reference to this paper should be made as follows:

Bhawana, Arvind Kumar Yadav (2019), "Causes and Effects of Industrial Disputes in BHEL India", Int. J. of Trade and Commerce-IIARTC, Vol. 8, No. 2, pp. 323-335 


\section{INTRODUCTION}

An industrial dispute is a manifestation of a disagreement and a difference of opinion between the two disputants, namely the employer and the workmen. The potential for conflicts exists in all human situations and organizations. A passive and subdued workforce is not conducive for good relationships. The relationships in the industrial relations system start with cooperation, soon change between the two into conflicts, and after they are resolved, change again into one of cooperation. This changing process is a continuous feature of the industrial relations system. Industrial disputes arise due to various causes, which may be classified into economic, organizational, physical, technical, political, psychological and market-oriented conditions. The workers are especially interested in higher wages, congenial working conditions, and opportunities for career advancement, welfare facilities, job satisfaction and the like. This dispute results in huge wastage of man-days and dislocation in the production work. It requires not a very imaginative mind to realize the consequences of a situation full of disputes. It is clear that the disputes have adverse effects on production, efficiency, cost, quality, human satisfaction, discipline, technological and economic progress and finally on the welfare of the society. Even in the absence of open confrontations resulting in strikes and lockouts, where the production comes to a halt and the costs and losses are apparent, the damaging effect of industrial conflict is too much wide spread and deep to be neglected. A discontented labour force cannot be efficient and will not possess a high degree of industrial morale. Under such conditions plant discipline breaks down both the quality and the quantity of production suffers and costs mount up causing harm to all concerned workers, employers and consumers.

\section{OBJeCtIVES OF THE STUDY}

- To study the main causes of Industrial Disputes,

- To study the main machinery of Industrial Disputes,

- To study the main causes and effects of Industrial Disputes in BHEL India.

\section{Research Methodology}

This paper is based on both primary and secondary data. For Primary Data we have collected data from employees of BHEL India through Questionnaire and personal Interview also conducted with them. And for secondary data we have consulted various books, journals, annual report and internet.

\section{CAUSES OF INDUSTRIAL DisPUTES}

Industrial disputes arise in innumerable of ways. A dispute could arise as a result of any demand raised by the workers to which management does not agree, irrespective of the nature of the demand. These days not only the employers and workers but also the government and the public are equally concerned about disputes, since conflicts, if not resolved in time, take the form of strikes and lockouts resulting in loss of profits, wages, production and supply of goods. Some of the ways to cope with industrial Disputes are recommended below:

a. Efforts to remove sources of conflict between the labour and the management through written agreement as soon as possible at the very first stage of negotiations.

b. Minimum wages should be maintained and as far as practicable, production standards should be defined in order to measure the productivity. 
c. Review the working conditions and terms of employers from time to time.

d. Continuous efforts to bridge the gap between the union and the management.

e. Implementation of social legislation applicable to the workers.

f. An effective grievance handling procedure.

g. Method of Arbitration to resolve the conflict at an early stage.

In India, the various measures of resolving Industrial disputes can be broadly categorized into statutory measures, Non-statutory measures, and Government sponsored guidelines. Statutory measures relate to the various type of machinery set up by government under the Labour Management Act, 1947 like labour courts, industrial and national tribunals etc. for specific conflicts which the government refers to the respective authorities.

Table - 1: No. of Disputes resolved by different methods of Settlement in BHEL

\begin{tabular}{|c|c|c|c|c|c|}
\hline S. No. & $\begin{array}{c}\text { Year Ended } \\
\text { March 31 }\end{array}$ & $\begin{array}{c}\text { Government } \\
\text { Intervention }\end{array}$ & $\begin{array}{c}\text { Mutual } \\
\text { Settlement }\end{array}$ & $\begin{array}{c}\text { Voluntary } \\
\text { Resumption }\end{array}$ & Total \\
\hline 1. & 2016 & 418 & 242 & 346 & 1006 \\
2. & 2017 & 372 & 233 & 318 & 923 \\
3. & 2018 & 212 & 236 & 382 & 830 \\
4. & 2019 & 318 & 252 & 422 & 992 \\
\hline
\end{tabular}

Source: Annual Report of BHEL, 2019

The above table shows the numbers of disputes resolved by government intervention, mutual settlement and voluntary resumption of the disputes.

Moreover, formation of works committees etc. are also statutorily provided for in order to see that the dispute is resolved in time. Several Non-statutory Measures like the code of Discipline, workers Participation in management, and Collective Bargaining, which is voluntary in nature are supported by Government and help in resolving the dispute. These Non statutory- Measures encourage a resolution through negotiation between the two parties and, thus, by their nature, speed up the third party can be considerably minimized. The labour department, both at the centre and the states have a considerable role to play in maintaining industrial harmony.

\section{Duties OF Disputes WORK COMMITTEE}

The Works Committee is an authority under the Act. The duties of the works Committee as stated are:

a. To promote measures for securing good relations between employers and workmen;

b. To achieve the above object, it is their duty to comment upon matters of common interest or concern of employers and workmen;

c. To endeavor to compose any material difference of opinion matters of common interest or concern in employers and workmen.

The main purpose of creating the works committee is to develop a sense of partnership between the employers and his workmen. It as a body which aims to promote goodwill and measures of common interest. These provisions are applicable only to such industrial establishment in which 100 or more workmen are employed, or to an establishment in which a minimum of 100 workmen 
have been employed on any day in preceding twelve months. The word 'workmen' in this section is used in the same sense in which it appears in section 2(s) of the Act. It means there must be 100 workmen and not 100 employees working in the establishment, many categories of employees are excluded from the definition of workmen. The appropriate government is authorized to require, by general or special order, the employers to constitute in the prescribed manner a works committee. The committee shall consist of representatives of employers and workmen engaged in the established. The number of representatives of workmen on the works committee shall not be less than the number of representatives of the employer. The representatives of the workmen shall be chosen in the prescribed manner from the workmen engaged in the establishment and in consultation with their trade union if any registered under the Indian Trade Union's Act, 1926.

The recommendations of the works committee where the workmen not fairly represented are of no value; the decision of the works committee carries great weight but is not conclusive. The decision of the works committee can be challenged if it is not fairly constituted or if the workmen are not fairly represented on it. The no of members constituting the works committee shall be fixed so as to afford representation to the various categories, groups classes of workmen engaged in, and to the sections, shops or departments of establishments. But the total number shall not exceed twenty. The representatives of the employers shall be nominated by the employer, and as far as possible, shall be officials in direct touch with or associated with the working of the establishment.

The workmen's representative on the committee shall be elected in two groups, namely:

1. Those to be elected by the workmen of the establishment who are members of the registered trade union or unions;

2. Those to be elected by the workmen of the establishment who are not members of the registered trade union.

\section{MACHINERY OF DISPUTES WORKS COMMITTEE}

Machinery of disputes works committee is as follows:

\subsection{Conciliation Officers}

The appropriate Government may by notification in the Official Gazette, appoint Conciliation Officers. These officers are charged with the duty of mediating in and promoting the settlement of Labour Management dispute. The appropriate Government may appoint one or more Conciliation Officers as it thinks fit. A Conciliation Officer may be appointed for a specified area, or for one or more specified industries.

Conciliation Officers have the same powers as are vested in a Civil Court under the Civil Procedure Court, 1908 in respect of compelling the production of documents. Conciliation Officers does not have the authority to summon and examine witnesses on oath. Conciliation Officer is a public servant, who has no jurisdiction to pass any orders. The Officer is expected to make conciliation efforts and mediation activities. His duties include:

a. Hold conciliation proceedings in the prescribed manner,

b. Investigate the matter of dispute without any delay and make all efforts to induce the parties to reach an amicable and fair settlement,

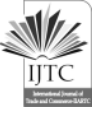


c. When a settlement is reached, he shall send a report to the appropriate Government along with a memorandum of the settlement signed by the parties,

d. If no settlement is reached, a full report should be sent to the appropriate Government which is the failure report, then the appropriate Government may refer the case to any other machinery namely Board, Labour Court, Court of Inquiry, Tribunal, National Tribunal, etc.,

e. A report should be submitted to the Government within 14 days. If either settlement report or failure report could not be submitted within the given period, during the pendency of the conciliation proceedings neither workers nor the management can call on any direct action, nor the employer shall alter the conditions of service of workmen.

The conciliation reports are important sources of information for policy making and the study of remedial measures in the field of Industrial Relations. The information contained in the reports may be useful for conciliation in a future dispute between the same parties.

\subsection{Boards of Conciliation}

The provision for appointment of Boards of Conciliation is made under the Act to bring the two parties to a dispute to sit together and thrash out their differences and to find out ways and means to settle them. The Act provides that the appropriate Government may, by notification in the Official Gazette constitute a Board of Conciliation. The object of appointing the Board is to make promotion of settlement of an Industrial Dispute. A Board shall consist of a Chairman and two or four other members, as the appropriate Government thinks fit.

It is to be noted that the Chairman must be an "independent person" which means a person unconnected with the Industrial Dispute or with any industry affected by such dispute. Of course, the appropriate Government is vested with the discretion to appoint the Board of Conciliation, whenever there is an occasion for such appointment on the arising of an Industrial Dispute. The Board as stated above is appointed with a view to promote the settlement of Labour Management.

The notice to the workmen shall be sent:

a. In case of workmen who are members of a Trade Union, to the President or Secretary of the Trade Union; and

b. In case of workmen who are not members of a Trade Union to any one of the five representatives of the workmen who have attested the application made under Rule 3 and in this case a copy of the notice shall also be sent to the employer who shall display copies thereof on notice boards in a conspicuous manner at the main entrance to the premises of the establishment.

\subsection{Arbitration}

Arbitration can either be voluntary or compulsory. Voluntary Arbitration implies that the two parties, unable to settle their differences between themselves or by the help of a mediator or conciliator, agree to submit their cases to an arbitrator whose decision they agree to accept.

The Government may prohibit any strike or lockout in connection with the dispute during arbitration proceedings. Besides the parties, others who are concerned with the dispute can also present their viewpoint before the Arbitrator. There can be more than one arbitrator, and in such 
a case if the arbitrators disagree, a provision has been made for the appointment of an umpire whose award will prevail.

The arbitrator can summon the parties involved in dispute, make a reference, call for the documents and hear the evidence and after hearing the parties concerned make an award which will be signed by both the parties.

The arbitrator or the Industrial Tribunal as an arbitrator, as the case may be forward the copies of the award made by him to the parties, the Commissioner of Labour, the Registrar and the State Government. On receipt of such award, an entry is made by the Registrar in the register kept for the purpose. The arbitration proceedings are deemed to have completed when the award is published.

\subsection{Court of Inquiry}

If any matter is referred to the Court by the appropriate Government, it shall inquire and make a report ordinarily within a period of six months from the commencement of inquiry. Section 6(1) points out that if "occasion arises" the appropriate Government may constitute a Court of Inquiry. The purpose of constitution of Courts of Inquiry is to inquire into any matter appearing to be connected with or relevant to an Industrial Dispute. The constitution of the Court has to be notified in the Official Gazette. Thus, it is clear that the proper occasion for appointment of a Court of Inquiry will be arising of an Industrial Dispute and necessary inquiry into any matter connected with or relevant to such dispute. The Court shall not inquire into the Industrial Dispute itself.

The Court may consist of one independent person or such number of independent persons as the appropriate Government thinks fit. Where a court consists of two or more members, one of them shall be appointed as the Chairman. If the court has the prescribed quorum it may act. The fact that the Chairman or any other member is absent or the existence of any vacancy in the court shall not debar the court from functioning provided the quorum exists. But if the appropriate Government notifies the court that the services of the Chairman have ceased to be available, the court shall not act until a new Chairman has been appointed. The appointment of a court together with the names of persons constituting it shall be notified in the Official Gazette.

The report of a court must be in writing and signed by all its members. Any member of a court is not prevented from recording any minute of dissent or from any recommendation made therein. Every report of a court together with any minute of dissent recorded therewith must be published within a period of 30 days from the date of its receipt by the appropriate Government.

On a perusal of the relevant sections pertaining to the court, of the Act it may be seen that during the pendency of a proceeding before a Court of Inquiry, the following rights remain unaffected, namely:

a. the right of a workman to go on strike;

b. the right of an employer to lock out his business; and

c. the right of employers to dismiss or otherwise to punish the workmen in certain cases under section 33 .

The idea of the court is borrowed from English Law where the report of the Courts of Inquiry is given wide publicity, and is placed before the House of Parliament, with a view to prevent and 
rectify any rash and precipitate action such as strike or lock out by the disputants for fear of public condemnation.

\section{LABOUR COURT AND INDUSTRIAL TRIBUNAL}

The final phase in the settlement of disputes which are not settled either through bipartite negotiations or through the good offices of the conciliation machinery, or through voluntary arbitration is compulsory arbitration or adjudication. The Labour Management Act provides for a three-tier system for adjudication of Labour Management. The machinery provided under the Act consists of Labour Courts, Industrial Tribunals and National Tribunals. These authorities acquire jurisdiction to adjudicate in a dispute under the order of reference issued by the appropriate government.

Whereas a Labour Court or an Industrial Tribunal can be constituted by an appropriate Government, a National Tribunal can be constituted only by the Central Government not with standing whether the subject matter referred to partains to the State Government or the Central Government.

Labour Courts can be constituted for dealing with the following matters and for performing such other functions as may be assigned to them under the Act:

a. The propriety or legality of an order passed by an employer under the Standing Orders;

b. The application and interpretation of the Standing Orders;

c. Discharge or dismissal of Workmen including re-instatement of or grant of relief to Workmen wrongfully dismissed;

d. Withdrawal of any customary concession or privilege;

e. Illegality or otherwise of a strike or lockout; and

f. All matters other than those specified to be within the jurisdiction of Industrial Tribunals.

Industrial Tribunals can be constituted for dealing with the following matters in addition to all those matters which fall within the jurisdiction of a Labour Court:

a. Wages, including the period and mode of payment;

b. Compensatory and other allowances;

c. Hours of work and rest intervals;

d. Leave with wages and holidays;

e. Bonus, profit sharing, provident fund, gratuity;

f. Shift working, otherwise than in accordance with Standing Orders;

g. Classification by grades;

h. Rules of discipline;

i. Rationalization;

A person shall not be qualified for appointment as the Presiding Officer of Labour Court unless:

a. he is, or has been, a judge of a High Court; or

b. he has, for a period of not less than 3 years, been a District Judge or an Additional District Judge; or

c. he has held the office of the Chairman or any other member of the Labour Appellate Tribunal or of any Tribunal for a period of not less than 2 years; or

d. he has held any judicial office in India for not less than 7 years; or 
e. he has been the Presiding Officer of a Labour Court under any Provincial Act or State Act for not less than 5 years. In order to be a Presiding Officer he must be an independent person and must not have attained the age of 65 years.

The parties to an Industrial Dispute apply either jointly or separately for a reference to the Government and after perusal the Government refers the matter to Labour Court/Industrial Tribunal for adjudication. The parties raising the dispute has to file a Statement of Claims along with documents and a list of witnesses and a copy of such statement is forwarded to the opposite party for their reply and comments. The Labour Court/Industrial Tribunal after receiving the reply frames the issue as per the order of reference. The evidences are recorded from both the aggrieved parties and finally the award is passed and published in the Official Gazette.

The Labour Court/Industrial Tribunal has powers to set aside the order of discharge or dismissal and direct re-instatement of the Workman on such terms and conditions as it thinks or give such other relief to the Workman including any lesser punishment as per the outcome of the fact of the cases. The jurisdiction of Labour Court is very much circumscribed. Its duty is to see whether the Domestic Inquiry satisfies the Principle of Natural Justice and where there was material for the Management to act in the manner they did and whether their act was not to victimize the Workman.

To sum up, we may say that the boundaries defined under the Act in regard to Labour Court and Industrial Tribunal can be described as -

The Court or Tribunal does not act as a court of appeal against the decisions of the Domestic Inquiry. It may interfere with the finding of a Domestic or a Managerial Inquiry when:

a. There is want of good faith, i.e. where employer is actuated by mala fides; or

b. There is victimization and unfair labour practice; or

c. the Management has been guilty of basic error or violation of Principles of Natural Justice; or

d. on the materials the finding is completely baseless or perverse; or

e. the acts of the employer or the finding of the Inquiry Officer is ultra vires e.g., contrary to the Standing Orders; or

f. where the penalty imposed is shockingly disproportionate to the charge found against the Workman.

\section{NATIONAL TRIBUNAL}

A National Tribunal can be constituted by the Central Government to deal with the dispute which in the opinion of the Central Government involves a question of national importance or is of such a nature that industrial establishments situated in more than one State are likely to be interested in or affected by such dispute. The subject matter of this dispute may relate to matters covered by the Second or Third Schedule.

All the three types of courts must consist one Presiding Officer only to be appointed by the appropriate Government.

Labour Courts and Tribunals are now required to submit award to the appropriate Government within the time specified in the order of reference which must not exceed three months in the case of individual disputes. 
Every award of a Labour Court, Industrial Tribunal or a National Tribunal must be published by the appropriate Government within 30 days from the date of its receipt. Unless declared otherwise by the appropriate Government every award shall come into force on the expiry of 30 days from the date of its publications and shall remain in operation for a period of one year thereafter.

According to Section 10(6) of Labour Management Act, 1947, when a reference had been made to a National Tribunal, then the following consequences shall ensure-

a. No labour Court or Tribunal shall have jurisdiction to adjudicate upon any matter which is under adjudication before the National Tribunal;

b. If the matter under adjudication before the National Tribunal is pending in a proceeding before a Labour Court or Tribunal, the proceeding before the Labour Court or Tribunal shall be deemed to have been quashed on such reference to the National Tribunal; and

c. It shall not be lawful for the appropriate Government to refer the matter under adjudication before the National Tribunal to any Labour Court or Tribunal for adjudication during the pendency of the proceeding in relation to such matters before the National Tribunal.

The National Tribunal is expected to hold adjudication proceedings expeditiously. This is for the purpose of establishing and maintaining industrial peace and harmony.

\section{Procedure for Disciplinary Action Under the STANDing ORders}

Although there are no statutory regulations regarding disciplinary procedure in our Industrial Law, the basic principle is one of natural justice. An employer has an inherent right to punish a wrong doer, the modern concept of social justice has to a great extent curbed this right and has imposed restrictions.

The employer is to observe certain formalities before inflicting punishment on an employee:

a. As far as possible, the first thing the employer should keep in mind is that his discretion to punish is to be used to the advantage of his employee - this discretion being used judicially.

b. The management must be extremely careful that they do not award a major punishment like dismissal, discharge, demotion and increment stoppage for a minor misconduct, even though a minor punishment like fine, suspension, warning or censure for a major misconduct is done in the circumstances of a case.

c. Disciplinary action generally starts with a complaint of misconduct against an employee. But where complaints are vague and fail to disclose all relevant facts, a preliminary investigation is necessary to ascertain facts.

d. The complaints are disposed of by the employer or his representative, in capacity of personal judgment. The employer will take no action for trifling complaints.

e. For minor offences, it will become necessary to take one of the following actions:

(i) An oral warning that shall not go in the employees' records.

(ii) Written warning letters that is also entered in the service records and is done so after obtaining explanation by the issuing of a charge sheet.

(iii) Awarding minor punishment of suspension or fine by following the disciplinary procedure of charge sheet and explanation of the wrong-doer. 
Major punishments can only be awarded after the complaint of some serious offence, a charge sheet being issued and a proper domestic enquiry having decided on the punishment. In such type of serious misconduct, the concerned employee may be suspended pending enquiry.

A departmental enquiry consists of four main stages, namely:

a) Charges

b) Investigation of the charge

c) Finding and punishment, and

d) Appeal

A domestic enquiry is not conducted with the rigidity of a judicial trial. The charge which is to be framed need not be framed with the precision of charge in a criminal proceeding. But it must not be vague or so general as to make it impossible of being overcome.

A workman guilty of misconduct may be:

a) Warned or censured, or

b) Fined subject to and in accordance with the provisions of the Payment of Wages Act, 1936,

c) Suspended by an order in writing signed by the Manager for a period not exceeding four days, or

d) Dismissed without notice.

Before any such order can be made, it is necessary to follow the Principles of Natural Justice. For example, the workman concerned must have been informed in writing of the alleged misconduct and given an opportunity to explain the circumstances alleged against him. In any case, no order of dismissal can be made except after holding an inquiry against the workman. If an inquiry is to be held, the workman must be given a charge sheet clearly setting forth the circumstances appearing against him and requiring his explanation. He must be permitted to appear himself for defending himself or to be defended by a workman working in the same department as himself of by any office-bearer of a trade union of which he is a member.

However, the workman can be suspended pending the inquiry. The order of suspension may take effect immediately on its communication to the workman. However, the workman so suspended is entitled, during the period of such suspension, to be paid a subsistence allowance as provided for in the Standing Orders applicable to him. In case the inquiry results in a decision not to take any action against the workman, the workman will be deemed to have been on duty and will be entitled to full wages minus such subsistence allowance as due to him.

In awarding punishment under the Standing Orders, the Manager must take into account the gravity of the misconduct, the previous record, if any, of the workman and any other extenuating or aggravating circumstances that may exist.

\section{Procedure of Settlement of Industrial Disputes in BHEL India}

There are two types of machinery provided under the Industrial Disputes Act, 1947 to settle the Labour Management. One is a Bi-partite Settlement in which the Union and the Management settle the dispute through collective bargaining and the terms of settlement are agreed upon and signed by both the parties. This proviso is described under the Act in Section-18. The above settlement is mandatory to be registered with the Labour Department. Secondly, the Tripartite settlement involves Union-Management/the Conciliation Officer. The Government becomes a signatory party in this settlement and it is applicable to all concerned.

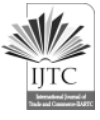


Apart from this, BHEL India has followed a grievance procedure for the prevention of disputes, the procedure consists of several stages in which any aggrieved employee may approach his immediate supervisor for the redressal of any complaint regarding his work, conditions pertaining to his work, etc. The supervisor will look into the complaint, discuss with his departmental head if necessary, who will, in turn, consult the Personnel Department if necessary and give a reply to the aggrieved employee within a period of 3 days to one week. If the aggrieved employee is not satisfied with the reply received from his supervisor, he may approach his departmental head, who will, in turn, investigate the matter personally and give a reply further within a period of 3 days to one week.

If the employee concerned is still not satisfied, he may approach the Factory Manager either personally or in writing for redressal of his complaint. The Factory Manager will look into the complaint and the reply given by him will be final in the matter. Such a reply is given generally within a week. If the employee still continues to be aggrieved, he may approach the Management through the Union when the matter is taken up at the Union-Management forum for settlement on tripartite basis or by adjudication/arbitration. If it is necessary for the workman to leave the work place on a call from any authority under this procedure, previous permission from his immediate superior should be obtained. If a grievance arises out of an order given by the Management, the said order shall be complied with before the workman concerned invokes the procedure laid down for redressal of grievance.

Table - 2: Table showing Level of Satisfaction among the Workers in regard to Grievance Settlement Procedure in BHEL India

\begin{tabular}{|l|c|c|}
\hline \multicolumn{1}{|c|}{ Level of Satisfaction } & No. of Respondents & Percent (\%) \\
\hline Satisfied & 64 & $32 \%$ \\
Dissatisfied & 137 & $54 \%$ \\
Indifferent & 28 & $14 \%$ \\
\hline Total & $\mathbf{2 0 0}$ & $\mathbf{1 0 0}$ \\
\hline
\end{tabular}

Source: Primary data

All these things show that there is no faith in Grievance Settlement Committee and, therefore, neither the Management, nor the workers, nor the Union intends to settle their grievances in this Committee; rather they prefer to settle them through adjudication procedure.

Under Section 3 or the Industrial Disputes Act, 1947, the provision of Works Committee is defined. It provides a representative method of settling of grievances arising out of and in course of employment related to the terms of employment. The elected members of employees and representatives of management settle the grievances related to conditions of work, safety provisions, welfare needs, holidays, etc. The members meet once in a month to settle the grievances but Table -3 shows the irregularity of meetings as under. 
Causes and Effects of Industrial Disputes in BHEL India

Bhawana, Arvind Kumar Yadav

Table -3: Table showing Works Committee's Meetings held in BHEL INDIA

\begin{tabular}{|c|c|c|}
\hline Year ended March 31 & Meetings Scheduled & Meetings Held \\
\hline 2016 & 12 & 10 \\
2017 & 12 & 9 \\
2018 & 12 & 7 \\
2019 & 12 & 8 \\
\hline
\end{tabular}

Source: Annual Report of BHEL, 2019

It can be seen from the above statistics that Works Committee is not being conducted at regular basis and there is no seriousness to settle the grievances. This type of attitude does not bring management and workers closer resulting they have no faith or priorities to settle the grievance or the dispute.

The workers/unions retaliate by taking up a fight with the management on every possible issue. The management is forced to settle the issues through adjudication process which consists of Conciliation Procedure, Court of Inquiry, Arbitration and Labour Courts/Tribunals. At present there is a great need of harmonious environment in the unit. Permanent peace can only be secured by mutual trust and voluntary agreement.

\section{CONCLUSION}

Both the management and the union should develop constructive attitudes towards each other. If the management does not fully accept the union or if the union leaders do not fully accept the system, harmonious industrial relations cannot be expected. Management must accept workers as equal partners of a joint venture. It must recognize their union as the spokesman of their grievances and as custodian of their interests. All basic policies and procedures relating to industrial relations should be clear to every one in the organization and to the union leaders. The management must make certain that the line people understand and agree with these policies. Failure to follow the spirit and letter of these policies can result in unnecessary misunderstanding and a deterioration of industrial relations.

The management should remove any distrust by convincing the union of their integrity, sincerity and honesty. Suspicious rumors and doubts should be put to rest immediately. They should not try to wean them away from the union. Workers feel, and rightly so, that they can be loyal to both their management and the union.

Management should encourage the right kind of union leadership. While it is not for the management to interfere with union activities, or choose the union leadership, its action and attitude goes a long way towards developing the right kind of union leadership. "Management gets the union it deserves" is not just an empty phrase. Management should create conditions which can stimulate growth of competent and constructive leadership.

And finally, after the settlement is reached, the agreement should be property administered. This involves the application, interpretation, and enforcement of the terms and conditions which the parties have agreed to both in letter as well as in spirit. 


\section{REFERENCES}

[1]. Agrawal, D., (2017). Industrial Relations and Collective Bargaining, Deep and Deep Publications, New Delhi.

[2]. Agrawal, R.D., (2018). Dynamics of Industrial Relations in India, Tata McGraw Hill Publishing Co. Ltd., Mumbai.

[3]. AITUC, Problems of Industrial Relations in India, p. 63.

[4]. Basu, D.D., (2005). Constitution Law of India, Prentice-Hall of India Pvt. Ltd., p. 127

[5]. Bethel, L.L., and Stackman, H.H (2016). At Water, Industrial Organisation and Management, F.J., Smith, G.H.E., p. 385.

[6]. Bhagoliwal, T.N., (2017). Economics of Labour and Industrial Relations, Sahitya Bhawan, Agra.

\section{Commission \& News Paper}

[1]. Indian Trade Union Act, 1926.

[2]. Industrial Disputes Act, 1947.

[3]. International Institute of Labour Studies, Bulletin 5, November, 2006.

[4]. International Labour Review, 2006.

[5]. Indian Journal of Industrial Relations.

[6]. Labour Pocket Books.

[7]. The Economic Times.

[8]. The Hindustan Times.

[9]. The Times of India.

[10]. The Indian Express. 